\title{
Total esophagogastrectomy in the neoplasms of the esophagus and esofagogastric junction: when must be indicated?
}

\section{Esofagogastrectomia total nas neoplasias do esôfago e transição esofagogástrica: quando deve ser indicada?}

Nelson Adami Andreollo, TCBC-SP1; João de Souza Coelho Neto, TGCB-SP²; Guilherme Delfino Calomeni'; Luiz Roberto Lopes, TCBC-SP'; VALDIR TERCIOTI JUNIOR, TCBC-SP'

\section{A}

\begin{abstract}
Objective: to analyse the indications and results of the total esophagogastrectomy in cancers of the distal esophagus and esophagogastric junction. Methods: twenty patients with adenocarcinomas were operated with a mean age of $55 \pm 9.9$ years (3170 years), and 14 cases were male (60\%). Indications were 18 tumors of the distal esophagus and esophagogastric junction (90\%) and two with invasion of gastric fundus (10\%) in patients with previous gastrectomy. Preoperative colonoscopy to exclude colonic diseases was performed in ten cases. Results: the surgical technique consisted of median laparotomy and left cervicotomy, followed by transhiatal esophagectomy associated with D2 lymphadenectomy. The reconstructions were performed with eight esophagocoloduodenoplasty and the others were Roux-en-Y esophagocolojejunoplasty to prevent the alkaline reflux. Three cases were stage I / II, while 15 cases (85\%) were stages III / IV, reflecting late diagnosis of these tumors. The operative mortality was 5 patients (25\%): a mediastinitis secondary to necrosis of the transposed colon, abdominal cellulitis secondary to wound infection, severe pneumonia, an irreversible shock and sepsis associated with colojejunal fistula. Four patients died in the first year after surgery: 3 (15\%) were due to tumor recurrence and 1 (5\%) secondary to bronchopneumonia. The 5 -year survival was $15 \%$. Conclusion: the total esophagogastrectomy associated with esophagocoloplasty has high morbidity and mortality, requiring precise indication, and properly selected patients benefit from the surgery, with the risk-benefit acceptable, contributing to increased survival and improved quality of life.
\end{abstract}

Key words: Adenocarcinoma. Esophagus. Surgical Procedures, Operative. Esophagectomy.

\section{INTRODUCTION}

$\mathrm{T}$ otal esophagogastrectomy and esophagocoloplasty is a complex surgical procedure, with mortality rates ranging from 2.5 to $29 \%$ and morbidity ranging from 13 to $75 \%$ in 1980-2010 published series. The magnitude of the operation and the severity of the disease which is the surgical indication are determining factors reported of the high morbidity and mortality'.

Esophageal reconstructions involving the colon are described since 1911 by variables causes ${ }^{2}$. The use of the colon and esophageal replacement is exceptional, once the stomach has better elasticity and vascularization. The total gastrectomy with concomitant esophagectomy is the main indication for esophagocoloplasty for the reconstruction of the digestive transit ${ }^{3-6}$.

The indications of total esophagogastrectomy are limited to certain conditions, particularly in radical resection of large tumors of the esophagogastric junction (EGJ) invading both viscera, esophageal tumors in patients with previous gastrectomy, severe caustic esophageal lesions with irreversible loss and stomach and congenital esophageal atresia ${ }^{7}$. Therefore, considering the rarity of conditions that require total esophagogastrectomy, such procedure is the absolute minority of resection surgeries performed in the esophagus and / or stomach, and few institutions had experience with this type of operation ${ }^{8-11}$.

The aim of this study is to analyse the indications and results of the total esophagogastrectomy in cancers of the distal esophagus and esophagogastric junction.

\section{METHODS}

From November 1989 to May 2011, 20 patients underwent total esophagogastrectomy followed by esophagocoloplasty at the Hospital de Clínicas da Unicamp. Of these, 14 (60\%) were male. The mean age of patients was $55,7 \pm 9,9$ years, ranging from 31 to 73 years. Eighteen patients were white $(90 \%)$ and two blacks $(10 \%)$.

1. Disciplina de Moléstias do Aparelho Digestivo e Gastrocentro, Departamento de Cirurgia, Faculdade de Ciências Médicas da Universidade Estadual de Campinas - Unicamp, Campinas, São Paulo, Brasil; 2. Programa de Pós-Graduação em Ciências da Cirurgia, Faculdade de Ciências Médicas - Unicamp, Campinas, São Paulo, Brasil. 
The main symptoms preoperatively reported were the weight loss in 16 patients (80\%), dysphagia in $15(75 \%)$ and heartburn (seven cases - 35\%). Tabagism was observed in 13 patients (55\%), alcohol consumption in $11(55 \%)$ and the combination of these two habits in 10 (50\%).

The most number had low body weight and therefore low BMI (body mass index). The weight ranged from $32 \mathrm{~kg}$ to $86 \mathrm{~kg}$ (mean: $63.66+/-13.85$ ) and BMI of 16.3 to 42.4 (mean: 23.8 +/- 5.4).

Among the surgical indications, there were a case of gastric stump tumor with distal esophageal invasion in late postoperative Billroth II gastrectomy performed in the other Service, for treatment of peptic ulcer (Siewert 3), an early adenocarcinoma in the Barrett's esophagus after Rouxen-Y gastrectomy previously operated in our Service, for treatment of gastroesophageal reflux disease (GERD), two advanced adenocarcinomas cases in Barrett's esophagus with esophageal and gastric invasion, and 16 cases of advanced adenocarcinomas of distal esophagus with invasion of the gastric fundus (Siewert 3). In none of them was possible the realization of the tumor resection with adequate surgical margin without removing en block the two organs involved, the esophagus and the stomach. Three cases $(15 \%)$ were in the stages I / II, while 17 cases (85\%) were in the stages III / IV, reflecting late diagnosis of these tumors (Table 1).

Ten patients underwent preoperative colonoscopy to exclude colonic diseases that contraindicated the esophagocoloplasty. The angiography to specific study of the intestinal vasculature was not performed. Mechanical preparation of the colon in the immediate preoperative period consisted of liquid diet and osmotic laxatives. The surgical technique used was described in the literature 10-12 $^{12}$

Were performed 20 total esophagogastrectomies and in all cases, surgical access consisted xypho-umbilical midline laparotomy and left neck incision, with an esophagectomy performed via transhiatal, with D2 lymphadenectomy. Reconstructions were performed in nine cases by esophacoloduodenoplasty and Roux-en-Y esophagocolojejunoplasty in 11 cases.

The decision on the colonic segment to be transposed and route of transposition was always taken in accordance with the findings of intraoperative evaluation. Firstly, were performed total mobilization of the ascending colon, and / or descending through the release of the parietocolic peritoneum. Then were identified the colic arteries employing transillumination and palpation. The feasibility of the colonic segment chosen was then assessed by selective clamping of colic pedicle to be connected. The transverse colon nourished by the left colic pedicle was used in all patients (100\%). The posterior mediastinal route option was 13 patients (65\%), while retrosternal route was used in seven patients (35\%). The continuity of colonic transit was restored by end-to-end manual anastomosis. The esophagocoloanastomosis was always performed in the neck, employing end-to-end manual technique in a single plane. Cervical drainage using a laminar drain was routine.

The integrity of the esophagocoloanastomosis was routinely assessed by contrast radiography on the eighth postoperative day or later. Fistula was defined as any leakage of contrast occurred, regardless of the presence of clinical manifestations. Outpatient follow-up consisted of reviews at least fortnightly during the first two postoperative months and quarterly for the first two years. Any complaint dysphagia was evaluated with upper digestive endoscopy being considered stenosis cases that required dilatation.

\section{RESULTS}

The average time of surgical hospitalization was $17,4 \pm 9,49$ days and the patient remained in the intensive care unit, on average, 5,85 $\pm 6,69$ days. During this period, 12 patients $(60 \%)$ presented clinical complications. Unilateral pleural effusion was noted in seven (35\%), requiring chest drainage in five of them (25\%). Bronchopneumonia was diagnosed in 3 patients (15\%). The mean follow-up was $31,1 \pm 62,9$ months with a maximum of 255 months.

Additional procedures were necessary in some patients (Table 2). The jejunostomy was performed in 17 patients (85\%). Splenectomy occurred in 17 patients (85\%), cholecystectomy in 13 (65\%), chest drain in 11 (55\%), caudal pancreatectomy in two (10\%) and hepatic nodulectomy in two $(10 \%)$.

Table 1 - Age, gender, surgical indications and staging.

\section{Age (years)}

Gender

Surgical Indications

Staging

\section{$55.75 \pm 9.93$}

$14 \quad(70 \%)$

$6(30 \%)$

Female

Adenocarcinoma of esophagogastric junction

Squamous cell carcinoma

$20(100 \%)$

$0 \quad(0 \%)$

I/II

$3(15 \%)$

III/IV
$17(85 \%)$ 
Surgical complications were diagnosed in six cases $(30 \%)$ during the immediate postoperative hospitalization. There was only one necrosis of the transposed colon (5\%), which was treated with resection of necrotic bowel, followed by cervical esophagostomy and jejunostomy. One patient presented acute intestinal obstruction by adhesions (5\%), and required surgical approach on the thirteenth postoperative day. Finally, in four cases were diagnosed cervical anastomotic leaks $(20 \%)$, three of them treated properly only with clinical measures (15\%). Were recorded two fistulas of the abdominal colonic anastomosis, treated medically and with total parenteral nutrition with favorable outcome.

Perioperative mortality observed was five cases $(25 \%)$, due to one mediastinitis secondary to necrosis of the transposed colon; one abdominal cellulitis secondary to wound infection that evolved to severe sepsis; one patient with irreversible shock at the end of the operation and died in the first postoperative day; one severe pneumonia with sepsis and cervical fistula; and one sepsis associated with abdominal fistula of the colojejunoanastomosis. It was not registered intra-operative mortality.

Neoadjuvant chemoradiotherapy was not employed because it is not the Service Protocol. However, six patients received adjuvant chemoradiotherapy.

Considering the long-term ambulatory follow-up, they can eat solids, soft and well cooked foods, and the most common complaint in cases submitted to esophagocoloduodenoplasty was the alkaline reflux. Due to this complaint greatly exacerbated, two patients underwent reoperation for conversion to Roux-en-Y esophagocolojejunoplasty. Thus, this latter technique was adopted as a routine in the Service after 2004. Moreover, stenosis of cervical anastomosis was diagnosed in three patients (15\%), and two of them appear in the cases that presented previous anastomosis fistula. In all cases, endoscopic dilations were sufficient to treat this complication. Left vocal cord paralysis secondary to recurrent laryngeal nerve injury was observed in one patient (5\%). There was no case of chylothorax or redundancy of the transposed colon.

Regarding late mortality, were recorded eight deaths (40\%), half of them before one year in the postoperative period, including two due to tumor recurrence; one due to a severe lack of appetite, malnutrition and unconfirmed tumor recurrence; and the other due to bronchopneumonia, pulmonary embolism and sepsis. All the deaths during the late follow-up after one year were due to tumor recurrence or metastasis.

The histopathologies studies revealed in three patients (17.6\%) involvement of radial margins. There was not, however, involvement of proximal and distal margins in any case. Tumor recurrence was recorded in nine patients $(45 \%)$, and occurred between two months to eight years and nine months after the operation, with an average of 24.2 months. Interestingly, in the group of patients with I stages, no recurrences or deaths were observed, and such complications were restricted to cases of advanced tumors. The five year survival was $15 \%$.

\section{DISCUSSION}

Few studies analyzing total esofagogastrectomies exist in contemporary literature. In fact, only a few specialized services perform this procedure. German authors

Table 2 - Surgical procedures performed.

\begin{tabular}{|c|c|c|c|}
\hline & Surgical Procedures & Number & of patients \\
\hline \multicolumn{4}{|l|}{ Resection } \\
\hline & Total esophagogastrectomy & 20 & \\
\hline \multicolumn{4}{|c|}{ Reconstruction } \\
\hline & Esophagocoloduodenoplasty & 9 & $(45 \%)$ \\
\hline & Roux-en-Y Esophagocolojejunoplasty & 11 & $(55 \%)$ \\
\hline \multicolumn{4}{|c|}{ Route of Reconstruction } \\
\hline & Posterior mediastinal & 13 & $(65 \%)$ \\
\hline & Retroesternal & 7 & $(35 \%)$ \\
\hline \multicolumn{4}{|c|}{ Colon Transposition } \\
\hline & Transverse colon (left colic artery) & 20 & $(100 \%)$ \\
\hline & Ascendent colon (middle colic artery) & 0 & $(0 \%)$ \\
\hline \multicolumn{4}{|c|}{ OtherProcedures } \\
\hline & Jejunostomy & 17 & $(85 \%)$ \\
\hline & Splenectomy & 17 & $(85 \%)$ \\
\hline & Cholecystectomy & 13 & $(65 \%)$ \\
\hline & Chest drainage & 11 & $(55 \%)$ \\
\hline & Caudal pancreatectomy & 2 & $(10 \%)$ \\
\hline & Hepatic nodulectomy & 2 & $(10 \%)$ \\
\hline
\end{tabular}


state that only $13 \%$ of medical institutions in the country have any experience with this surgery ${ }^{8,9}$. In published series of esophageal resection, total esofagogastrectomy represent no more than $10 \%$ of the procedures $5^{5,12,13}$.

The mainly indication for such a complex operation are restricted and tumors of esophagogastric junction, and the minority that affect large portions of the esophagus and stomach, extrapolating Siewert classification (14). The advanced nature of these tumors at the time of diagnosis, justifies the prognosis of patients ${ }^{10,14-17}$. This characteristic is clear in this series of cases, of which $80 \%$ belonging to stages III and IV.

The stomach is considered the main viscera for the reconstruction of the upper digestive tract, and of course the concomitant gastrectomy prevents such procedure, requiring the esophagocoloplasty, and in these cases it is predominant the esophageal squamous cell carcinoma. Among benign diseases, severe cases of caustic stenosis with concomitant esophageal and gastric lesions are the main indications. And such patients usually attempted prior endoscopic treatment employing dilations, but did not obtain satisfactory results $2-4,18-22$

The advantages of using the colon as esophageal substitute include its good vascularization, its long extension and its relative resistance to acid reflux. The disadvantages involve longer surgical time and the need for two extra anastomoses $5,12,23,24$. In fact, many current studies show that the use of the colon esophageal replacement determines higher morbidity, but the mortality is the same ${ }^{3,21}$.

There is no consensus as to the best colonic segment for transposition. There are authors that recommend the right colon and others who prefer the left. Similarly, there is controversy on the issue of better transposition pathway. Proponents of retrosternal route claim that infectious complications would be less disastrous ${ }^{6}$, while supporters of the posterior mediastinal route emphasize the shortest distance and better functional results ${ }^{12,20}$. This study shows the functional quality of transposition through posterior mediastinal, dependent on the left colic pedicle, because it occurred to just one case of transposed colon necrosis case and no registered redundancy.

The total esophagogastrectomy associated with esophacoloplasty makes more complex the operation, justifying the high levels of morbidity and mortality associated. Postoperative complications vary from 41 to $67 \%$ in the contemporary literature, mainly the pneumonia, pleural effusion and fistulas In fact, cervical anastomosis fistulas are from 5.8 to $46 \%$ of the cases $5,8,12,17,19,21,24$. Despite the frequency of this complication, treatment with oral fasting or soft diet associated with cervical drainage is resolving most of the time. Fortunately, transposed colon necrosis is rare, ranging from 0 to $9.4 \%$ and its outcome is often the patient's death. Finally, stenosis of the cervical anastomosis, late complication, occurs in $6-46 \%$ of cases with an endoscopic dilation treatment usually efficient. Regarding mortality associated with the procedure are values between 0 and $17 \%$, with survival rates at five years between 10 and $48 \%$ These values reflect the severity of the disease 5,8,12,19,21,24,25.

Tumor recurrence affects the prognosis and quality of life of patients after total esofagogastrectomy. Factors associated with higher cancer recurrence risks include tumor differentiation, advanced stage, lymph node invasion and involvement of surgical margins. Treatment of local recurrence is extremely complex, with greater difficulty in the posterior mediastinal transposition ${ }^{26-28}$. The recurrence recorded in the patients described here was restricted to stages III and IV, attesting to the greater relevance of tumor aggressiveness.

The study in our Service ${ }^{27}$, including 103 patients with adenocarcinoma of the esophagogastric junction, comparing 78 submitted to surgical treatment with 25 submitted to the operation followed by chemoradiation, using the protocol of Macdonald et al., showed no increase in survival at five years of follow-up.

Publications reporting this procedure in the literature are rare. Moreno-Gonzalez et a/16 in Spain, reported three cases of total esophagogastrectomy in advanced tumors of esophagogastric junction. Abularach C et al. ${ }^{18}$ in Chile, reported the same surgery in five cases of tumors of esophagogastric junction, patients with a mean age of 50 years, mean hospital stay of 20 days, without mortality. Munoz-Bongrand et $a^{\Upsilon^{2}}$. describe the surgical technic of the total esophagogastrectomy emphasizing the need for a jejunostomy for postoperative parenteral nutrition, and extensive drainage of the peritoneal cavity due to the risk of postoperative fistula. Yasuda et $a^{\beta 0}$ emphasize that the reconstruction of the digestive tract should preferably be isoperistaltic and using posterior mediastinum. This procedure has the advantage that a shorter path, however, has the disadvantage of occurrence of colon necrosis, which is fatal. Conclude that it is a procedure with high risk of complications and not negligible mortality.

Finally, there are few studies evaluating quality of life of patients undergoing total esophagogastrectomy. The most of them lose weight, but eventually stabilize at a new level that will not compromise your health, usually around $90 \%$ of preoperative weight $t^{6,11,29}$. Yasuda et $a^{\beta 0}$. reported that the functional result of esophagocoloplasty looks worse than the reconstruction with gastric tube, but acceptable regarding the need of the patient. Other studies $^{6,9,12,31}$ have shown that after three months of surgery, 49 to $78 \%$ of patients report good food intake, and this figure rises to 82 to $89 \%$ with one year of the procedure. The main symptoms reported in the late outpatient treatment include dysphagia (10 to $40 \%$ ), reflux (8 to $24 \%$ ), diarrhea (10 to $39 \%$ ) and dumping syndrome (24\%).

Concluding, the total esophagogastrectomy associated with esophagocoloplasty are a high morbidity and mortality procedure, therefore requiring precise indication, with the risk-benefit acceptable. The results of the procedures performed in our Service are similar to those 
of the best international centers, encouraging us to continue to hold such a large operation, for the benefit of the patient, both in survival and in improving their quality of life.

\section{R E S U M O}

Objetivo: avaliar as indicações e resultados da esofagogastrectomia total seguida de esofagocoloplastia, nas neoplasias do esôfago distal e da transição esofagogástrica. Métodos: foram avaliados os dados epidemiológicos, o quadro clínico, a indicação cirúrgica, o tipo de reconstrução, as complicações clínicas e cirúrgicas e a mortalidade. Resultados: Nas reconstruções foram realizadas oito esofagocoloduodenoplastias e as demais foram esofagocolojejunoplastias em Y de Roux, visando prevenir o refluxo alcalino. Três casos eram estádios IIII, enquanto 15 (85\%) casos eram estádios IIIIV, refletindo o diagnóstico tardio destes tumores. A mortalidade operatória foi cinco pacientes (25\%): uma mediastinite secundária à necrose do cólon transposto, uma celulite abdominal secundária à infecção de ferida operatória, uma broncopneumonia grave, um choque irreversível e uma sepse associada à fístula colojejunal. Quatro doentes morreram no primeiro ano de pós-operatório, sendo que três (15\%) deveram-se à recidiva tumoral e um (5\%) secundário à broncopneumonia. A sobrevida de cinco anos foi 15\%. Conclusão: a esofagogastrectomia total associada à esofagocoloplastia apresenta elevada morbimortalidade, necessitando indicação precisa. Os pacientes corretamente selecionados beneficiam-se da operação, sendo o risco-benefício aceitável, contribuindo para o aumento da sobrevida e melhora da qualidade de vida.

Descritores: Adenocarcinoma. Esôfago. Procedimentos Cirúrgicos Operatórios. Esofagectomia.

\section{REFERENCES}

1. Bernard A, Obadia JF, Arnould H, Cougard P, Viard H. Factors influencing survival after resection of cancer of the cardia. Comparison of total esophagogastrectomy and upper pole esophagogastrectomy. Ann Chir. 1990;44(6):459-63.

2. Celiku E, Draçini $X$, Dibra A, Maturo A. Surgical treatment of the adenocarcinoma of the cardia. G Chir. 2011;32(8-9):353-6.

3. Cerfolio RJ, Allen MS, Deschamps C, Trastek VF, Pairolero PC. Esophageal replacement by colon interposition. Ann Thorac Surg. 1995;59(6):1382-4

4. Davis PA, Law S, Wong J. Colonic interposition after esophagectomy for cancer. Arch Surg. 2003;138(3):303-8.

5. DeMeester SR. Colon interposition following esophagectomy. Dis Esophagus. 2001;14(3-4):169-72.

6. DeMeester TR, Johansson KE, Franze I, Eypasch E, Lu CT, McGill $J E$, et al. Indications, surgical technique, and long-term functional results of colon interposition or bypass. Ann Surg. 1988;208(4):46074.

7. Doki Y, Okada K, Miyata H, Yamasaki M, Fujiwara Y, Takiguchi S, et al. Long-term and short-term evaluation of esophageal reconstruction using the colon or the jejunum in esophageal cancer patients after gastrectomy. Dis Esophagus. 2008;21(2):132-8.

8. Fürst H, Hüttl TP, Löhe F, Schildberg FW. German experience with colon interposition grafting as an esophageal substitute. Dis Esophagus. 2001;14(2):131-4.

9. Popovici Z. A new philosophy in esophageal reconstruction with colon. Thirty-years experience. Dis Esophagus. 2003;16(4):323-7.

10. Lundell L, Olbe L. Colonic interposition for reconstruction after resection of cancer in the esophagus and gastroesophageal junction. Eur J Surg. 1991;157(3):189-92.

11. Greene CL, DeMeester SR, Augustin F, Worrell SG, Oh DS, Hagen $J A$, et al. Long-term quality of life and alimentary satisfaction after esophagectomy with colon interposition. Ann Thorac Surg. 2014;98(5):1713-9; discussion 1719-20.

12. Munoz-Bongrand N, Chirica M, Sarfati E. Transverse coloplasty, left coloplasty, colon interposition, reconstruction after total esophagogastrectomy. J Chir. 2009;146(6):559-64.

13. Pompeo E, Nofroni I, Van Raemdonck D, Coosemans W, Van Cleynenbreughel B, Lerut T. Esophagocoloplasty for congenital, benign and malignant diseases. Surgical and long-term functional results. Eur J Cardiothorac Surg. 1996;10(7):561-7; discussion 567-8.
14. Rüdiger Siewert J, Feith M, Werner M, Stein HJ. Adenocarcinoma of the esophagogastric junction: results of surgical therapy based on anatomical/topographic classification in 1,002 consecutive patients. Ann Surg. 2000;232(3):353-61.

15. Bîrlã R, losif C, Mocanu A, Gîndea C, Hoarã P, Panaitescu E, et al. Long-term survival after eso-gastrectomy for esophagogastric junction adenocarcinoma-prospective study. Chirurgia. 2008;103(6):635-42.

16. Gonzalez EM, Garcia JI, Selas PR, Azcoita MM, Garcia JI, Gonzalez JS. Extented esophago-gastretomy as surgical treatment for carcinoma of the cardia. Jpn J Surg. 1981;11(5):311-6.

17. Schiesser M, Schneider PM. Surgical strategies for adenocarcinoma of the esophagogastric junction. Recent Results Cancer Res. 2010;182:93-106.

18. Abularach CR, Venturelli MF, Cerda CR, Urizar GA, Lira EE, Haito $C Y$, et al. Transverse colon interposition as an alternative to reconstruction after total esophagogastrectomy. Rev Chil Cir. 2011;63(4):432-6.

19. Moreno González E. Cancer of the cardia: the value of total extended esophago-gastrectomy. Cancer Treat Res. 1991;55:205-46.

20. Motoyama S, Kitamura M, Saito R, Maruyama K, Sato Y, Hayashi $\mathrm{K}$, et al. Surgical outcome of colon interposition by the posterior mediastinal route for thoracic esophageal cancer. Ann Thorac Surg. 2007;83(4):1273-8.

21. Cheng BC, Xia J, Shao K, Mao ZF, Huang J, Wang TS. Surgical treatment for upper or middle esophageal carcinoma occurring after gastrectomy: a study of 52 cases. Dis Esophagus. 2005;18(4):239-45.

22. Feith M, Stein HJ, Siewert JR. Adenocarcinoma of the esophagogastric junction: surgical therapy based on 1602 consecutive resected patients. Surg Oncol Clin N Am. 2006:15(4):751-64.

23. Hüttl TP, Wichmann MW, Geiger TK, Schildberg FW, Fürst $H$. Techniques and results of esophageal cancer surgery in Germany. Langenbecks Arch Surg. 2002;387(3-4):125-9.

24. Butte JM, Becker F, Visscher A, Waugh E, Meneses M, Court I, et al. Adenocarcinoma of the esophagogastric junction: retrospective analysis of 39 patients. Rev Med Chil. 2010;138(1):53-60.

25. Klink CD, Binnebösel M, Schneider M, Ophoff $K$, Schumpelick V, Jansen M. Operative outcome of colon interposition in the treatment of esophageal cancer: a 20-year experience. Surgery. 2010;147(4):491-6. 
26. Shirakawa $Y$, Naomoto $Y$, Noma K, Sakurama K, Nishikawa T, Nobuhisa $T$, et al. Colonic interposition and supercharge for esophageal reconstruction. Langenbecks Arch Surg. 2006;391(1):19-23.

27. Tercioti-Júnior V, Lopes LR, Sallum RAA, Andreollo NA, Malafaia O. Terapia adjuvante associada à esofagectomia melhora a sobrevida nos pacientes portadores de adenocarcinoma da junção esofagogástrica? ABCD, arq bras cir dig. 2013;26(2):77-9.

28. Popovici Z. A new concept in esophageal reconstruction with colon (considerations on 329 operated cases). Chirurgia. 2002;97(6):5238.

29. Cense HA, Visser MR, van Sandick JW, de Boer AG, Lamme B, Obertop $\mathrm{H}$, et al. Quality of life after colon interposition by necessity for esophageal cancer replacement. J Surg Oncol. 2004;88(1):328.

30. Yasuda T, Shiozaki H. Esophageal reconstruction with colon tissue. Surg Today. 2011;41(6):745-53.
31. Mine S, Udagawa $H$, Tsutsumi K, Kinoshita $Y$, Ueno M, Ehara K, et al. Colon interposition after esophagectomy with extended lymphadenectomy for esophageal cancer. Ann Thorac Surg. 2009;88(5):1647-53.

Received at: 15/05/2015

Accepted for publication: 20/07/2015

Conflict of interest: none.

Source of funding: none.

\section{Mailing address:}

Nelson Adami Andreollo

E-mail: nandreollo@hotmail.com 